\title{
Cytotoxicity and Sterilization Resistance of Electronic Components for Disposable Smart Biomedical Devices
}

\begin{abstract}
The design of Smart Biomedical Devices will be a defining element of future research in the context of intelligent medical devices for the Internet of Medical Things (IoMT). A prerequisite for serving the disposable market is the use of cost-effective electronic components and the highest reliability of the developed products in terms of biocompatibility and bioprotection. In the study, resistors, capacitors, and light-emitting diodes, different in their materials and construction forms, were examined. The selected types represented electronic components as they are commonly installed on electronic system from the segment of low-cost standard components. These were subjected to steam sterilization with up to 50 cycles, gamma sterilization, and a CCK-8 assay to test in vitro cytotoxicity. Functional failure could not be determined for any component. Gamma sterilization did not result in significant changes in resistance values, but in capacitors with barium titanate as dielectric. Non-cytotoxic electronic components could be identified. The results show that certain electronic standard components are suitable for disposable Smart Biomedical Devices.
\end{abstract}

Keywords: Biocompatibility, cytotoxicity, sterilization, electronic components, Smart Medical Devices

https://doi.org/10.1515/cdbme-2019-0075

\section{Introduction}

In recent years, the Internet of Medical Things (IoMT) has become increasingly important in all areas of medical technology [1]. For the medical device market, the

\footnotetext{
${ }^{*}$ Corresponding author: Valerie M. K. Werner: Institute of Medical and Polymer Engineering, Technical University of Munich, Garching, Germany, e-mail: valerie.werner@tum.de Daniel Strömsdörfer, Viet Nga Bui, Niklas von Wittenburg, Markus Eblenkamp: Institute of Medical and Polymer Engineering, Technical University of Munich, Garching, Germany
}

development of IoMT products, which are used for diagnostic and therapeutic purposes [2], presents new and highly demanding challenges. In particular, the development of disposable or limitedly reusable smart medical devices with embedded electronic components, which are essentially in the context of modern in vitro diagnostics, will be a future research focus [3]. For biomedical products, this means that the plastic components equipped with electronics must be biologically compatible. The materials used must therefore be examined for their sterilizability and biocompatibility $[4,5]$. Sterilization processes expose electronic components to extreme conditions such as high humidity and temperature or high-energy radiation. Products for multiple applications are often prepared with steam, disposables are industrially sterilized with gamma rays [6]. The demand for autoclavable electronic components is the subject of current research and product developments [7]. Biocompatibility refers to a compatible interaction of a technical system with the biological conditions [8]. The release of potentially toxic foreign substances must be prevented by suitable encapsulation [9-11]. Electronic components contain a large number of materials (e.g. copper, nickel, manganese) [12] which have a toxic effect on biological systems at high concentrations [13]. Today's electronic components usually have plastic housings (packages) that have a certain resistance to environmental conditions [14]. Plastics show, however, a permeation - the pressure or concentration-related mass transport through a solid - of water from the air or through water storage [15]. Consequently, plastics form a nonhermetic seal around electronics. In order to address this problem, electronic assemblies are protected from climatic and operational stresses by means of superordinate protective coatings $[16,17]$. The use of already non-cytotoxic package materials around the electronic structures minimizes the risk of toxic components escaping if protective coatings fail.

The disposable market is mainly driven by costs, which means that commercially available mass electronics are moving into the focus of interest. Passive components, such as resistors and capacitors, and active components, such as light 
emitting diodes, usually represent an almost negligibly small part of the costs of IoT and IoMT systems. A failure of these components, on the other hand, can lead to the defect of further - often more expensive - components and thus cause an overriding system damage. The number of passive components installed accounts for the largest proportion of printed circuit boards controlled by microcontrollers. The most frequently used components for the realization of circuits are resistors, semiconductors and capacitors [18]. For example, a microcontroller IC requires a multiple of resistors and capacitors in its standard circuit. An extensive investigation of the effects of environmental conditions in the application on functionality and reliability is therefore of the highest priority. [19]

In our study we therefore examined common electronic standard components in steam sterilization up to 50 cycles, gamma sterilization with a typical dose of $25 \mathrm{kGy}$ and cytotoxicity according to the requirements of the standard for the biological evaluation of medical devices DIN EN ISO 10993-5. The aim was to make statements on resistance by means of well-founded observations of the influences of the load spectrum humidity and temperature, radiation as well as toxic behavior of the electronic components.

\section{Materials and Methods}

\subsection{Electrical Components}

A representative selection of components with regard to different materials was made. The criteria for the selection were low cost segment, standard packages and low tolerances.

RESISTORS. Fixed resistors of the layer resistor type were selected according to the designs Through-Hole Technology Device (THT) and Surface Mounted Device (SMD) and differentiated according to resistor type and material composition (see Table 1). The most commonly used package size for THT resistors is 0207 followed by 0204 [20].

CAPACITORS. Four different capacitors of the commercial grade class were selected for the test series. A foil capacitor and a sintered tantalum electrolytic capacitor from the THT series were investigated, while ceramic multilayer capacitors of type 1 with low (NDK, $\left.\varepsilon_{N D K}=10 \ldots 200\right)$ and type 2 with high dielectric constant $\left(\mathrm{HDK}, \varepsilon_{H D K}=10,000\right)$ were tested as SMD representatives (see Table 2).

LIGHT-EMITTING DIODES (LEDs). LEDs were selected as semiconductor representatives (see Table 3). LEDs are manufactured from semiconductor materials such as noncytotoxic silicon ( $\mathrm{Si}$ ) or carcinogenic gallium arsenide (GaAs).
Table 1: Technical data and materials of the investigated resistors according to manufacturer's specifications.

\begin{tabular}{|c|c|c|c|c|}
\hline \multirow{2}{*}{$\begin{array}{l}\text { Manufac. } \\
\text { Part } \\
\text { Number }\end{array}$} & \multirow{2}{*}{$\begin{array}{l}\text { Yageo } \\
\text { RC0603FR- } \\
0710 \mathrm{KL}\end{array}$} & \multicolumn{3}{|c|}{ TE Connectivity } \\
\hline & & $\begin{array}{l}\text { CPF0603F10 } \\
\text { KC1 }\end{array}$ & $\begin{array}{l}\text { CFR100J10 } \\
\mathrm{K}\end{array}$ & $\begin{array}{l}\text { LR0204F10 } \\
\text { K }\end{array}$ \\
\hline Type & Thick film & Thin film & Carbon film & Metal film \\
\hline Package & SMD 0603 & SMD 0603 & THT 0207 & THT 0204 \\
\hline Resistance & $10 \mathrm{k} \Omega \pm 1 \%$ & $10 \mathrm{k} \Omega \pm 1 \%$ & $10 \mathrm{k} \Omega \pm 5 \%$ & $10 \mathrm{k} \Omega \pm 1 \%$ \\
\hline Resistor & $\begin{array}{l}\text { Precious } \\
\text { metal, glass }\end{array}$ & NiCr alloy & Carbon & NiCr alloy \\
\hline $\begin{array}{l}\text { End contact, } \\
\text { wire }\end{array}$ & $\mathrm{Ni} / \mathrm{Sn}$ & Sn & $\begin{array}{l}\text { Metal } \\
\text { Sn, Cu }\end{array}$ & $\begin{array}{l}\text { Metal } \\
\text { Sn, Cu }\end{array}$ \\
\hline $\begin{array}{l}\text { Protective } \\
\text { layer }\end{array}$ & $\begin{array}{l}\text { Glass, } \\
\text { epoxy resin }\end{array}$ & Epoxy resin & $\begin{array}{l}\text { phenolic/ } \\
\text { epoxy resin }\end{array}$ & $\begin{array}{l}\text { phenolic/ } \\
\text { epoxy resin }\end{array}$ \\
\hline
\end{tabular}

Table 2: Technical data and materials of the tested capacitors according to manufacturer's specifications.

\begin{tabular}{|c|c|c|c|c|}
\hline Manufac. & Kemet & Kemet & Yageo & $A V X$ \\
\hline Part number & $\begin{array}{l}\text { R82EC2100 } \\
\text { DQ50K }\end{array}$ & $\begin{array}{l}\text { C0603C101J } \\
\text { 5GACTU }\end{array}$ & $\begin{array}{l}\text { CC0603KR } \\
\times 7 R 7 B B 104\end{array}$ & $\begin{array}{l}\text { TAP106K01 } \\
6 \text { SCS }\end{array}$ \\
\hline Type & Thick film & Thin film & Carbon film & Metal film \\
\hline Package & $\begin{array}{l}\text { THT } 7.2 \times 2.5 \\
\times 6.5(\mathrm{~mm})\end{array}$ & SMD 0603 & SMD 0603 & $\begin{array}{l}\text { THT I: } 9 \mathrm{~mm} \text {, } \\
\text { diam.: } 5 \mathrm{~mm}\end{array}$ \\
\hline Capacity & $10 \mathrm{nF} \pm 10 \%$ & $100 \mathrm{pF} \pm 5 \%$ & $100 \mathrm{nF} \pm 10 \%$ & $10 \mu \mathrm{F} \pm 10 \%$ \\
\hline Dielectric & $\begin{array}{l}\text { Polyester, } \\
\text { PET }\end{array}$ & $\mathrm{CaZrO}_{3}$ & $\begin{array}{l}\mathrm{CaZrO}_{3} \text { or } \\
\mathrm{BaTiO}_{3}\end{array}$ & $\mathrm{Ta}_{2} \mathrm{O}_{5}$ \\
\hline $\begin{array}{l}\text { Contact, } \\
\text { Wire }\end{array}$ & $\begin{array}{l}\text { Al or Zn } \\
\text { Sn-Cu }\end{array}$ & Sn & $\mathrm{NiSn}$ & $\begin{array}{l}\text { Sn (cath.) } \\
\text { Ta (anode) }\end{array}$ \\
\hline Cover/Filler & Plastic/resin & - & $E$ & Epoxy resin \\
\hline
\end{tabular}

Table 3: Technical data and materials of the examined LEDs according to manufacturer's specifications.

\begin{tabular}{l|l|l}
\hline Manufacturer & Opto Supply & Lucky Light \\
\hline Part number & OSG50603C1E & LL-S194PUYC-Y2-2B \\
\hline Type & Thick film, SMD 0603 & Thin film, SMD 0603 \\
\hline Forward voltage & $2.5-3.4 \mathrm{~V}$ & $1.6-2.4 \mathrm{~V}$ \\
\hline Color & green & yellow \\
\hline Semiconductor & \multicolumn{2}{|c}{ AlGalnP } \\
\hline Protective capsule & \multicolumn{2}{|c}{ Epoxy resin } \\
\hline Leadframe & CuNi alloy, Au Plating & CuNi alloy \\
\hline
\end{tabular}

CYTOTOXICITY. Generally zinc (Zn), nickel (Ni) and copper $(\mathrm{Cu})$ are classified as cytotoxic. Aluminium (Al), silver-palladium alloy $(\mathrm{AgPd})$, gold $(\mathrm{Au})$, barium titanate $\left(\mathrm{BaTiO}_{3}\right)$, calcium zirconate $\left(\mathrm{CaZrO}_{3}\right)$, manganese dioxide $\left(\mathrm{MnO}_{2}\right)$, Polyethylene terephthalate (PET), silver (Ag), silverpalladium alloy (AgPd), tantalum (Ta), tantalum pentoxide $\left(\mathrm{Ta}_{2} \mathrm{O}_{5}\right)$, and tin $(\mathrm{Sn})$ are listed in the literature as noncytotoxic and biocompatible [21, 22]. No blanket statement can be made for epoxy resins. Since these mostly form the 


\section{DE GRUYTER}

V. M. K. Werner et al., Cytotoxicity and Sterilization Resistance of Electronic Components for Disposable Smart Biomedical Devices — 299

sheath material around the components, there is a need for individual testing for biological compatibility. Due to the mostly internal toxic components, knowledge about the barrier effect of the outer layers can be gained over the test duration and the associated corrosion situation on the package material.

\subsection{Sterilization Processes}

STEAM STERILIZATION. Before sterilization, a functional test was carried out using digital technology. A total of five test series for steam sterilization were carried out: single, five-, ten-, 25-, and 50-fold. The electronic components were repackaged in sterilization packaging for the experiments after each cycle. The hot steam sterilization was carried out with the parameter combination $121^{\circ} \mathrm{C}, 20 \mathrm{~min}, 2$ bar. After $24 \mathrm{~h}$ of drying and cooling of the samples under laboratory conditions, the electrical values were recorded.

GAMMA RADIATION. The electronic components packaged in ESD bags were gamma sterilized at a dose of $29.1 \mathrm{kGy}$ to $41.7 \mathrm{kGy}$. Gamma rays have a highly energetic and ionising effect, so that changes in the material structure can be caused long after the sterilization process. The test samples were therefore stored under ambient conditions and measured electrically after 14, 28 and 42 days.

\subsection{Cell Culture}

The biocompatibility test for cytotoxicity was carried out in vitro using CCK-8 assay using an eluate test according to DIN EN ISO 10993-5. Human fibroblasts of cell line Hs 27 were used. The tinned copper connecting wires of the THT capacitors were isolated by non-cytotoxic silicone, and from the THT resistors completely removed. This allowed focussing on cytotoxicity and barrier effect of the plastic packages. The eluate was prepared using Dulbecco's Modified Eagle Medium (DMEM), incubated at $37^{\circ} \mathrm{C}, 10 \% \mathrm{CO}_{2}, 72 \mathrm{~h}$. The Hs 27 cells inoculated with the eluates were incubated for $72 \mathrm{~h}$. The evaluation was performed with WST-8 reaction solution and absorption measurement using a photometer.

\section{Results and Discussion}

\subsection{Sterilization}

After the up to 50 -fold sterilization by means of saturated steam has been carried out, no functional failure of any component can be detected in the electrical function test. The average resistance values and their changes of the resistors are shown in Figure 1, the average capacity changes in Figure 2.

(a)

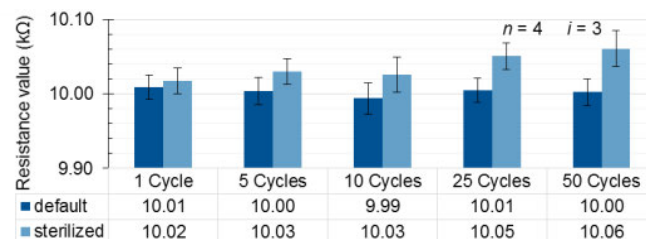

(b)

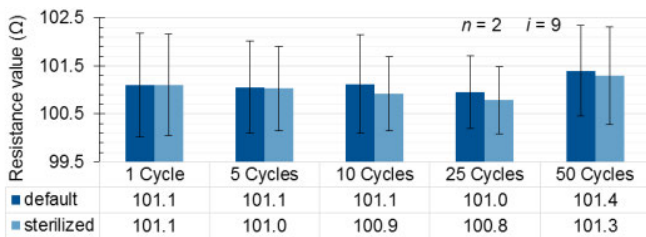

(c)

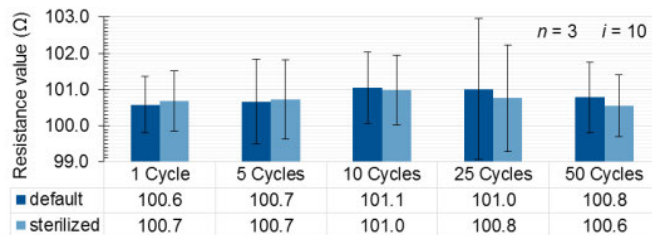

Figure 1: Results of the electrical parameters unsterilized (default) and after up to 50 cycles steam sterilization (sterilized) of resistor types a) thin film, b) carbon layer, c) metal layer.

Overall, the changes in the resistance values were within the tolerance range of the components. Device-specific measurement tolerances of the multimeter used had to be taken into account. In principle, the penetration of water vapour into the electronic packages promotes ageing of the materials and corrosion, which favours changes in resistance.

(a)

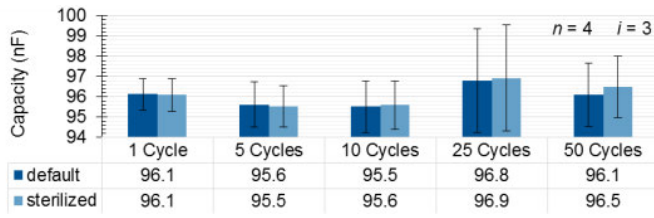

(b)

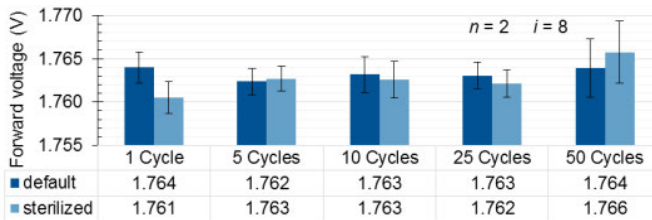

Figure 2: Results of the electrical characteristics unsterilized (default) and after up to 50 cycles of steam sterilization (sterilized) of a) ceramic capacitors type 2 , b) yellow LEDs.

The capacitance values determined for all capacitors after sterilization were within the component tolerance range of $10 \%$. Negative effects on the SMD LEDs due to steam sterilization couldn't be determined. Non-significant changes in the through-voltages were detected. 
Figure 3 shows the results of gamma sterilization of the tested electrical components. The resistance values of the thinfilm resistors showed no measurable changes 42 days after gamma sterilization and are therefore not shown.

(a)
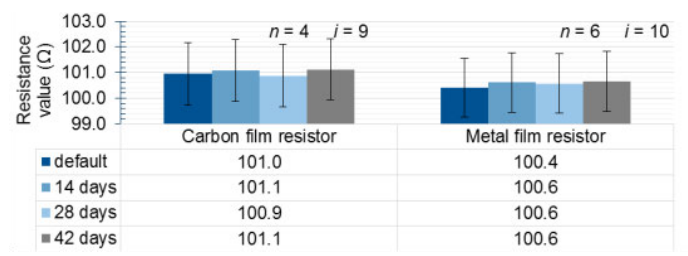

(b)

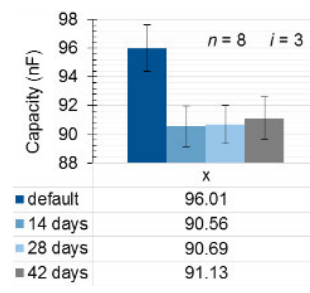

(c)

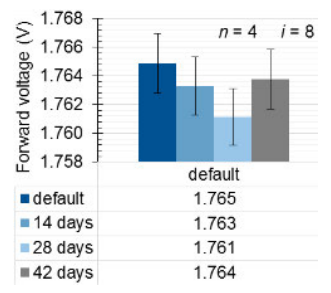

Figure 3: Results of electrical parameters unsterilized (default) and after gamma sterilization of a) carbon and metal resistors, b) ceramic capacitor type 2, c) yellow LEDs.

The resistors proved to be functionally stable, changes were not significant. 14 days after the irradiation of the capacitors, a significant decrease in capacitance of approx. $5.7 \%$ was observed. Measurements of the LEDs showed a decreasing trend of the mean forward voltage. The irradiation of polymer materials with gamma rays can cause effects such as chain splitting and cross-linking in the polymer [23]. The cleavage of molecular chains leads to a decrease in molecular weight, which leads to embrittlement. Crystal dislocations and ionization of semiconductor materials have different effects on electrical properties [24]. Dielectrics based on barium titanate with a radiation dose of up to $0.5 \mathrm{kGy}$ show a decrease in crystal size [25]. Structurally, barium titanate remains after irradiation, but a change of the structure can be detected by changing the lattice parameters [26]. This can lead to a deterioration of the ferroelectric properties.

\subsection{Electronic packages cytotoxicity}

Figure 4 shows the results of the cytotoxicity test. In the mean value, the SMD resistors were above the $70 \%$ limit (noncytotoxic), THT resistors at the threshold. When the tinned copper wires were removed, open entrances remained where remaining copper particles could not be excluded. The results show that the epoxy protective layer of the thin film resistor has a sufficient barrier effect on the $\mathrm{NiCr}$ alloy. The hermetically sealed resistance layer of the thick film resistor also has a sufficiently protective effect.

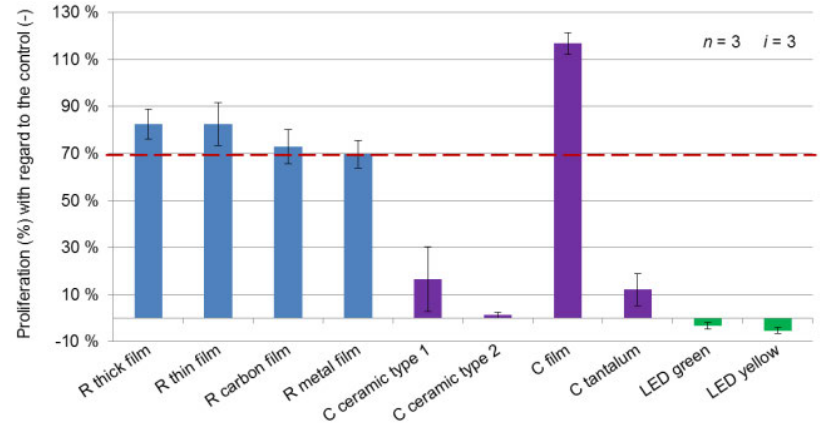

Figure 4: Results of the cytotoxicity test using CCK-8 assay for resistors (blue), capacitors (purple), and LEDs (green).

The unspecified epoxy resin package of the tantalum capacitor was cytotoxic. The cytotoxicity of the ceramic capacitors was caused by the ceramic body or the tin-coated electrodes. An influence of the underlying nickel and copper may also have contributed to the death of the cells. The shell of the foil capacitors made of a plastic that could not be determined more precisely did not react cytotoxically. The value of more than $100 \%$ proliferation can be explained by uneven seeding of the cells (larger cell count leads to metabolism of larger volumes and thus to higher proliferation values in comparison to the reference) in the wells or by media change (eluate inoculation) and thus a nutrient boost for the cells, which the control did not receive. For miniaturized electronic assemblies, ceramic and tantalum capacitors are preferable to foil capacitors. Film capacitors, however, are characterized by high dielectric strength and have the advantage of self-healing [18], which means that they can be advantageous for corresponding applications.

The eluates of the tested LEDs had a strong cytotoxic effect. Corrosion was observed at the terminal contacts of the components. The metallic frame made of a copper-nickel alloy can be regarded as the cause here.

\section{Conclusion}

The study showed that the electronic components were not significantly damaged functionally by steam sterilization with 50 cycles. The percentage change was less than $0.5 \%$ of the initial values. Gamma sterilization of resistors did not lead to significant changes in resistance values. Capacitors with the dielectric barium titanate were found to be highly susceptible to gamma radiation. Non-cytotoxic electronic components could be identified. The results show that certain electronic standard components are suitable for the realization of disposable Smart Biomedical Devices. 


\section{Author Statement}

The authors state no funding involved and no conflict of interest.

\section{References}

[1] Andelfinger VP. Industrie 4.0: Wie cyber-physische Systeme die Arbeitswelt verändern. Wiesbaden: Springer Fachmedien Wiesbaden 2017.

[2] Medizinproduktegesetz in der Fassung der Bekanntmachung vom 7. August 2002 (BGBI. I S. 3146), das zuletzt durch Artikel 7 des Gesetzes vom 18. Juli 2017 (BGBI. I S. 2757) geändert worden ist.

[3] Bürdek BE. Design: Geschichte, Theorie und Praxis der Produktgestaltung. s.l.: Birkhäuser Verlag 2005.

[4] Bowman L, Meindl JD. The packaging of implantable integrated sensors, 2. IEEE Transactions on Biomedical Engineering 1986: 248-255.

[5] George J, Compagno T, Rodgers K, Waldron F, Barrett J. Reliability of plastic-encapsulated electronic components in supersaturated steam environments, 10 (5). IEEE Transactions on Components, Packaging and Manufacturing Technology 2015: 1423-1431.

[6] Ha S-W, Koller M, Göllner G. Sterilisation. In: Wintermantel E, Ha S-W, editors. Medizintechnik: Life Science Engineering; Interdisziplinarität, Biokompatibilität, Technologien, Implantate, Diagnostik, Werkstoffe, Zertifizierung, Business. 5th ed.: 113-125.

[7] SCHOTT AG. Autoclavable, custom-designed LEDs: SCHOTT Solidur ${ }^{\circledR}$ LEDs provide hermetic protection for challenging medical and dental applications. Landshut, Germany. Available from: URL:https://www.schott.com/epackaging/german/autoclavab le_and_hermetic_leds.html [cited 2019 May 24].

[8] Wintermantel E, Ha S-W, editors. Medizintechnik: Life Science Engineering; Interdisziplinarität, Biokompatibilität, Technologien, Implantate, Diagnostik, Werkstoffe, Zertifizierung, Business. 5th ed.

[9] Donaldson N, Baviskar P, Cunningham J, Wilson D. The permeability of silicone rubber to metal compounds, 3 (100). Journal of Biomedical Materials Research Part A 2012: 588598.

[10] Kalweit A, Paul C, Peters S, Wallbaum R. Handbuch für Technisches Produktdesign. Material und Fertigung, Entscheidungsgrundlagen für Designer und Ingenieure. 2nd ed.: Springer-Verlag 2012.

[11] Uhlemann J, Schindler S, Schlottig G, et al. Cytotoxicity of COB materials. IEEE 2005: 593-596.

[12] Wellmann P. Materialien der Elektronik und Energietechnik: Halbleiter, Graphen, Funktionale Materialien. Wiesbaden: Springer 2017.
[13] Ewers U, Brockhaus A. Metal concentrations in human body fluids and tissues. In: Merian E, editor. Metals and Their Compounds in the Environment: Occurence, Analysis, and Biological Relevance. Weinheim: VCH Verlagsgesellschaft; 1991: 207-220.

[14] Bressler K, Rudolph H. Transistoren. In: Hering E, Bressler $\mathrm{K}$, Gutekunst J, editors. Elektronik für Ingenieure und Naturwissenschaftler. Berlin, Heidelberg: Springer Berlin Heidelberg; 2017: 167-258.

[15] Hellerich W, Harsch G, Haenle S. Werkstoff-Führer Kunststoffe: Eigenschaften, Prüfungen, Kennwerte. 10th ed. s.l.: Carl Hanser Fachbuchverlag 2010.

[16] Zhuang X, Nikoozadeh A, Beasley MA, Yaralioglu GG, KhuriYakub BT, Pruitt BL. Biocompatible coatings for CMUTs in a harsh, aqueous environment, 5 (17). Journal of Micromechanics and Microengineering 2007: 994.

[17] Werner VMK, Artmann L, Eblenkamp M. Schutzschild für Elektronik und Körper: Barrierewirkung polymerer Beschichtungen zur Kapselung von Smart Biomedical Devices. Kunststoffe: $45-48$.

[18] Stiny L. Passive elektronische Bauelemente: Aufbau, Funktion, Eigenschaften, Dimensionierung und Anwendung. 2nd ed. Wiesbaden: Springer Vieweg 2015.

[19] Gallay R. Metallized Film Capacitor Lifetime Evaluation and Failure Mode Analysis. CERN Yellow Report CERN-2015003 2016: 45-56.

[20] Beuth K. Bauelemente. 19th ed. s.l.: Vogel Buchverlag 2010.

[21] Wintermantel E, Ha S-W, editors. Medizintechnik: Life Science Engineering; Interdisziplinarität, Biokompatibilität, Technologien, Implantate, Diagnostik, Werkstoffe, Zertifizierung, Business. 5th ed.

[22] Zhang D, Wong CS, Wen C, Li Y. Cellular responses of osteoblast-like cells to 17 elemental metals. Journal of biomedical materials research. Part A 2017; 105: 148-158.

[23] Gad SC, Gad-McDonald S. Biomaterials, medical devices, and combination products: Biocompatibility testing and safety assessment. Boca Raton, London, New York: CRC Press Taylor \& Francis Group 2016.

[24] Brumbi D. Bauelemente-Degradation durch radioaktive Strahlung und deren Konsequenzen für den Entwurf strahlenresistenter elektronischer Schaltungen. Bochum: Ruhr-Universität Bochum 1990.

[25] Ahmadu U, Abubakar S, Bidemi Abdulwaliyu U, Muhammad M, Uthman I. Structural and microstructural study of gamma ray-irradiated co-doped barium titanate (Ba0.88Ca0.12Ti0.975Sn0.025O3). PAC 2016; 10: 79-85.

[26] Ivers-Tiffée $E$, Münch Wv. Werkstoffe der Elektrotechnik. 10th ed. Wiesbaden: B.G. Teubner Verlag / GWV Fachverlage GmbH Wiesbaden 2007. 
